\title{
Structures of the Metabolites from Steviol Methyl Ester by Gibberella fujikuroi
}

\author{
Yoshio Shigematsu, Noboru Murofushi and Nobutaka TakaHASHI \\ Department of Agricultural Chemistry, The University of Tokyo, \\ Bunkyo-ku, Tokyo 113, Japan
}

Received April 9, 1982

\begin{abstract}
Steviol methyl ester (methyl ent-13-hydroxykaur-16-en-19-oate)* was converted into five new metabolites together with a known compound, methyl ent-7 $\alpha$,13-dihydroxykaur-16-en-19-oate, by Gibberella fujikuroi in the presence of a plant growth retardant. The structures of these new metabolites were elucidated to be methyl ent-7 $\beta, 13$-dihydroxykaur-16-en-19-oate, methyl ent$11 \alpha, 13$-dihydroxykaur-16-en-19-oate, methyl ent-7 $\beta, 11 \alpha, 13$-trihydroxykaur-16-en-19-oate, methyl ent-11 $\alpha, 13,15 \beta$-trihydroxykaur-16-en-19-oate and methyl ent-13,15 $\beta$-dihydroxy-11-oxokaur-16-en19-oate mainly by spectroscopic analyses.
\end{abstract}

The microbial conversions of steviol and its derivatives by Gibberella fujikuroi in the presence of a plant growth retardant were reported in the preceding paper. ${ }^{1)}$ The metabolites from steviol and its acetate were all identified as the known compounds. Steviol methyl ester (1), however, was converted into several new compounds. Here, we wish to report the details of their isolation and structural determination.

One hundred and fifty milligrams of steviol methyl ester (1) was incubated with G. fujikuroi under the same conditions as in the case of steviol. ${ }^{1)}$ After a nine day incubation the culture filtrate was fractionated by solvent partitioning to afford an ethyl acetate-soluble neutral fraction. The fraction was chromatographed with a partition column and the eluates were further purified by thin layer chromatography (TLC) to afford six compounds, A, B, C, D, E, and F. Their ${ }^{1} \mathrm{H}$ NMR spectral features suggested that they retain the ent-kaurene skeleton without any fission in the rings.

The information on their molecular formulae and the number of hydroxyls was obtained through mass spectral data. The structural elucidation was achieved mainly by ${ }^{1} \mathrm{H}$
NMR spectral analyses. In Table I, the chemical shifts and coupling constants of significant signals of the metabolites are summarized. They were assigned by extensive comparative studies together with spin-decoupling experiments.

Compound A and its trimethylsilyl (TMS) derivative gave the molecular ion peak at $\mathrm{m} / \mathrm{z}$ 348 and $m / z$ 492, respectively, in their mass spectra, suggesting that $\mathbf{A}$ is a methyl ester of monohydroxylated steviol. The carbinol proton signal at $\delta 3.93 \mathrm{ppm}$ in the NMR spectrum is quite similar to that of $7 \beta$-hydroxysteviol (12). ${ }^{1,2)}$ Treatment of 12 with ethereal diazomethane afforded $\mathbf{A}$, confirmed by gas-liquid chromatography (GLC) and mass spectrometry. Thus, A was identified as the methyl ester of $7 \beta$-hydroxysteviol (2).

Compound $\mathbf{B}$ and its TMS derivative gave mass spectra quite similar to those of $\mathbf{A}$ and its TMS derivative, respectively, suggesting that $\mathbf{B}$ is the stereoisomer of $\mathbf{A}$. A carbinol proton signal in the NMR spectrum of $B$ resembles that of ent-7 $\beta$-hydroxykaur-16-en-19-ol $(13)^{3)}$ prepared from the methyl ester of 7-oxokaurenoic acid by a lithium aluminum hydride reduction. If the presence of ent-7 $\beta$-hydroxyl group is assumed, the chemical shift of the ent-

* As to nomenclature, refer to the footnote in the preceding paper. 
Table NMR Data of the Metabolites from Steviol Methyl Ester (measured in pyridine- $d_{5}$ )

\begin{tabular}{|c|c|c|c|c|c|c|c|c|}
\hline \multicolumn{9}{|c|}{ Chemical shift, $(J, \mathrm{~Hz})$} \\
\hline & & $5-\mathrm{H}$ & $6 \alpha-\mathrm{H}$ & $6 \beta-\mathrm{H}$ & 7-H & $11-\mathrm{H}$ & $12 \alpha-\mathrm{H}$ & $12 \beta-\mathrm{H}$ \\
\hline $\mathbf{A}$ & (2) & & & & $\begin{array}{l}3.93 \\
\text { (br. s) }\end{array}$ & & & \\
\hline B & (3) & $\begin{array}{l}1.20(\mathrm{dd}) \\
(13,2)\end{array}$ & $\begin{array}{l}2.22(q) \\
(13)\end{array}$ & $\begin{array}{l}2.41 \text { (br. d) } \\
\text { (13) }\end{array}$ & $\begin{array}{c}3.61(\mathrm{dd}) \\
(12,4)\end{array}$ & & & \\
\hline $\mathbf{C}$ & (5) & & & & & $\begin{array}{l}4.40(d) \\
(5)\end{array}$ & $\begin{array}{l}2.42(\mathrm{dd}) \\
(5,14)\end{array}$ & $\begin{array}{l}254 \text { (br. d) } \\
\text { (14) }\end{array}$ \\
\hline D & (6) & $\begin{array}{l}1.34(\mathrm{dd}) \\
(2,13)\end{array}$ & $\begin{array}{l}2.24(q) \\
(13)\end{array}$ & $\begin{array}{c}2.46 \text { (br. d) } \\
\text { (13) }\end{array}$ & $\begin{array}{l}3.72(\mathrm{dd}) \\
(4,12)\end{array}$ & $\begin{array}{l}4.48(d) \\
(6)\end{array}$ & $\begin{array}{l}2.55(\mathrm{dd}) \\
(6,13)\end{array}$ & $\begin{array}{l}2.66 \text { (br. d) } \\
\text { (13) }\end{array}$ \\
\hline $\mathbf{E}$ & (9) & & & & & $\begin{array}{l}4.45(d) \\
(5)\end{array}$ & $\begin{array}{l}2.49(\mathrm{dd}) \\
(5,14)\end{array}$ & $\begin{array}{l}2.60(\mathrm{br} \mathrm{d}) \\
(14)\end{array}$ \\
\hline $\mathbf{F}$ & (11) & & & & & - & $\begin{array}{l}3.16(d) \\
(14)\end{array}$ & $\begin{array}{l}3.03 \text { (br. d) } \\
(14)\end{array}$ \\
\hline
\end{tabular}

TABLE (contd.)

\begin{tabular}{|c|c|c|c|c|c|c|c|c|c|}
\hline & & $14 \alpha-H$ & $14 \beta-H$ & $15 \alpha-H$ & $15 \beta-H$ & $17-\mathrm{H}$ & $17-\mathrm{H}$ & $18-20-\mathrm{H}_{3}$ & $\mathrm{COOCH}_{3}$ \\
\hline $\mathbf{A}$ & (2) & & & $\begin{array}{l}2.83 \text { (br. dt) } \\
(2.5,16)\end{array}$ & $\begin{array}{l}2.70 \text { (br. dq) } \\
(2.5,16)\end{array}$ & 5.08 (br. s) & 5.50 (br. s) & $\begin{array}{l}1.30(\mathrm{~s}) \\
1.42(\mathrm{~s})\end{array}$ & $3.62(\mathrm{~s})$ \\
\hline $\mathbf{B}$ & (3) & & & $\begin{array}{l}3.44 \text { (br. dt) } \\
(2.5,17)\end{array}$ & & $\begin{array}{l}5.07(\text { br. t) } \\
(2.5)\end{array}$ & $\begin{array}{l}5.54 \text { (br. q) } \\
(2.5)\end{array}$ & $0.94(\mathrm{~s})$ & $3.58(\mathrm{~s})$ \\
\hline C & (5) & & & $\begin{array}{l}2.30 \text { (br. dt) } \\
(2.5,17)\end{array}$ & $\begin{array}{l}3.12 \text { (br. dq) } \\
(2.5,17)\end{array}$ & 5.06 (br.) & $\begin{array}{l}561(\text { br. q) } \\
(2)\end{array}$ & $\begin{array}{l}0.84(\mathrm{~s}) \\
1.18(\mathrm{~s})\end{array}$ & $3.63(\mathrm{~s})$ \\
\hline D & (6) & $\begin{array}{l}2.05 \text { (br. d) } \\
(12)\end{array}$ & & $\begin{array}{l}3.54(\text { br. dt }) \\
(2.5,16)\end{array}$ & $\begin{array}{l}3.11 \text { (br. dq) } \\
(2.5,16)\end{array}$ & $\begin{array}{l}5.13 \text { (br. q) } \\
(2.5)\end{array}$ & $\begin{array}{l}5.67 \text { (br. q) } \\
(2.5)\end{array}$ & $\begin{array}{l}0.91(\mathrm{~s}) \\
1.20\end{array}$ & $358(\mathrm{~s})$ \\
\hline $\mathbf{E}$ & (9) & $\begin{array}{l}2.39 \text { (br. d) } \\
(12)\end{array}$ & $\begin{array}{l}2.17 \text { (br. d) } \\
(12)\end{array}$ & - & 5.23 (br. s) & $\begin{array}{l}5.75(\text { br. t) } \\
(1.5)\end{array}$ & $\begin{array}{l}5.86(\text { br. } t) \\
(1.5)\end{array}$ & $\begin{array}{l}0.91(\mathrm{~s}) \\
1.18(\mathrm{~s})\end{array}$ & $3.63(\mathrm{~s})$ \\
\hline $\mathbf{F}$ & (11) & $\begin{array}{l}2.46 \text { (br. d) } \\
(12)\end{array}$ & $\begin{array}{l}2.72 \text { (br. d) } \\
(12)\end{array}$ & - & 4.18 (br. s) & 5.61 (br. s) & 5.81 (br. s) & $1.00(\mathrm{~s})$ & $3.64(\mathrm{~s})$ \\
\hline
\end{tabular}

$15 \beta$-proton can be explained by the deshielding effect of the hydroxyl located nearby. The stereoisomeric relationship between $\mathbf{A}$ and $\mathbf{B}$ was established by the identity of their oxidation products. A was oxidized with Jones reagent to afford 7-oxosteviol methyl ester (4). B was also treated with the same reagent and the main product was identified as 4 by GLC and GC-MS analysis. Consequently, $\mathbf{B}$ was determined to be $7 \alpha$-hydroxysteviol methyl ester (methyl ent-7 $\beta, 13$-dihydroxykaur-16-en19-oate, 3).

Compound $\mathbf{C}$ is a monohydroxylated steviol methyl ester. A carbinol proton signal was observed as a doublet at $\delta 4.40 \mathrm{ppm}$ in the NMR spectrum. It couples with one of the geminal protons $(\delta 2.42 \mathrm{ppm}, \mathrm{dd}, J=5 \mathrm{~Hz}$, $14 \mathrm{~Hz}$ ), another proton being observed at $\delta 2.54 \mathrm{ppm}$ (br. d, $J=14 \mathrm{~Hz}$ ). The possible position of the secondary hydroxyl group to accommodate this spectral data is $\mathrm{C}-11$, where the proton in the $\alpha$-configuration (equatorial) shows clear coupling with the $12 \alpha$-proton, but only slight coupling with the 9-proton and $12 \beta$-proton due to their dihedral angles being close to $90^{\circ}$. The presence of an $11 \beta$-hydroxyl 
is supported by the down-field shift of the $15 \beta$ proton signal by the deshielding effect of the hydroxyl. Thus, $\mathbf{C}$ can be assigned to $11 \beta$ hydroxysteviol methyl ester (methyl ent$11 \alpha, 13$-dihydroxykaur-16-en-19-oate, 5).

Compound $\mathbf{D}$ is a dihydroxysteviol methyl ester. In the NMR spectrum two carbinol proton signals at $\delta 3.72$ and $4.48 \mathrm{ppm}$ can be attributed to a $7 \beta$-proton and $11 \alpha$-proton, respectively, by comparing the spectra of $\mathbf{D}$ with those of $\mathbf{B}$ and $\mathbf{C}$. Since it is known that ent-11 $\alpha$-hydroxykaurenoids form an ether linkage between $\mathrm{C}-11$ and $\mathrm{C}-16$ by treatment with mineral acid, ${ }^{4 \sim 6)}$ the same conversion was attempted for $\mathbf{D}$, which was obtained in better yield than C. D was treated with acetic acid under a mild condition to prevent rearrangement in the $\mathbf{C} / \mathbf{D}$ ring. The products were analyzed by GC-MS and NMR, and the main product was found to be an isomer of $\mathbf{D}$

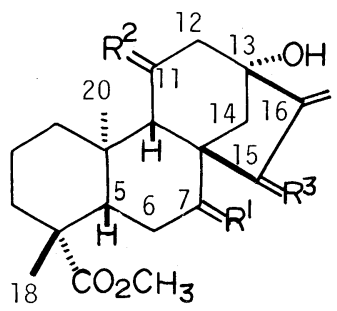

$$
\begin{array}{ll}
1 & R^{1}=R^{2}=R^{3}=H_{2} \\
2 & R^{1}=\alpha-H, \beta-O H, R^{2}=R^{3}=H_{2} \\
3 & R^{1}=\alpha-O H, \beta-H, R^{2}=R^{3}=H_{2} \\
4 & R^{1}=0, R^{2}=R^{3}=H_{2} \\
5 & R^{1}=H_{2}, R^{2}=\alpha-H, \beta-O H, R^{3}=H_{2} \\
6 & R^{1}=\alpha-O H, \beta-H, R^{2}=\alpha-H, \beta-O H, R^{3}=H_{2} \\
7 & R^{1}=R^{2}=H_{2}, R^{3}=\alpha-O H, \beta-H \\
8 & R^{1}=R^{2}=H_{2}, R^{3}=0 \\
9 & R^{1}=H_{2}, R^{2}=\alpha-H, \quad \beta-O H, R^{3}=\alpha-O H, \beta-H \\
10 & R^{1}=H_{2}, R^{2}=R^{3}=0 \\
11 & R^{1}=H_{2}, R^{2}=0, R^{3}=\alpha-O H, \beta-H
\end{array}
$$

with three tertiary methyls and two hydroxyls. IR and CD spectrum did not show the presence of a ketone group in the product, suggesting that a Wagner-Meerwein rearrangement has not occurred. Therefore, the conversion product must be the compound having an ether linkage (15). All these data indicate that the structure of $\mathbf{D}$ is $\mathbf{6}$.

$\mathbf{E}$ is dihydroxysteviol methyl ester. One carbinol proton was assigned to the $11 \alpha$-proton because the signal at $\delta 4.45 \mathrm{ppm}$ and a couple of signals at $\delta 2.49$ and $2.60 \mathrm{ppm}$ were very similar to the signals of the $11 \alpha-, 12 \alpha$ - and $12 \beta$ proton in $\mathbf{D}$, respectively. A characteristic feature in the NMR spectrum of $\mathbf{E}$ is in exocyclic methylene protons, which resonate in a lower field than those in $\mathbf{A}, \mathbf{B}, \mathbf{C}$ and $\mathbf{D}$, suggesting the presence of a hydroxyl in C-15. To confirm this, steviol methyl ester (1) was treated with selenium dioxide. The product (7), where a

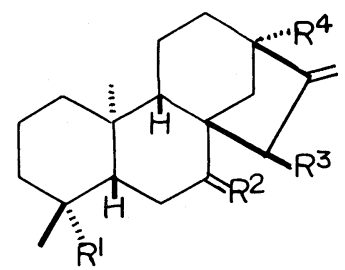

$12 R^{\top}=\mathrm{CO}_{2} \mathrm{H}, \mathrm{R}^{2}=\alpha-\mathrm{H}, \quad \beta-\mathrm{OH}, \mathrm{R}^{3}=\mathrm{H}, \mathrm{R}^{4}=\mathrm{OH}$

$13 \mathrm{R}^{1}=\mathrm{CH}_{2} \mathrm{OH}, \mathrm{R}^{2}=\alpha-\mathrm{OH}, \quad \beta-\mathrm{H}, \mathrm{R}^{3}=\mathrm{R}^{4}=\mathrm{H}$

$14 \mathrm{R}^{1}=\mathrm{CH}_{2} \mathrm{OH}, \mathrm{R}^{2}=\mathrm{H}_{2}, \mathrm{R}^{3}=\mathrm{R}^{4}=\mathrm{OH}$
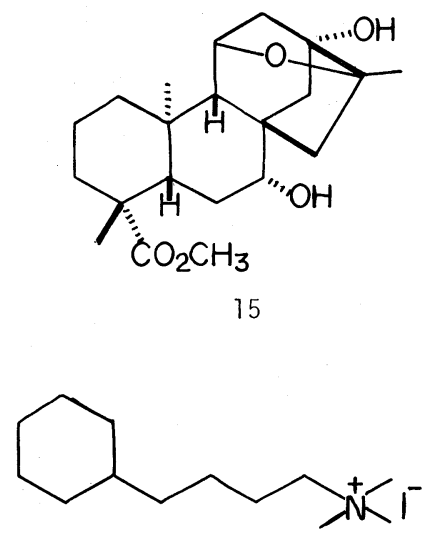

16 
hydroxyl should have been introduced into the $\alpha$-configuration due to the attack of the reagent from the less hindered $\alpha$-side, revealed the exomethylene proton signals with a chemical shift only slightly higher than those of $\mathbf{E}$. The lower chemical shift of the 15-proton in $\mathbf{E}$ than than in 7 indicates that the proton has a $\beta$ configuration and is deshielded by the $11 \beta$ hydroxyl. The $\alpha$-configuration of the 15 -hydroxyl in $\mathbf{E}$ was also confirmed by the shape of the $15 \beta$-proton signal. Its shape is quite similar to that of the $15 \beta$-proton signal in 7 but different from that of the $15 \alpha$-proton signal in 14 which was prepared from 7 by a Jones oxidation followed by lithium aluminum hydride reduction. Thus, the structure of $\mathbf{E}$ was assigned to 9.

Compound $\mathbf{F}$ has two hydroxyls and its molecular weight is smaller than that of $\mathbf{E}$ by two. The exomethylene proton signals of $\mathbf{F}$ are similar to those of $\mathbf{E}$ to indicate the presence of a $15 \alpha$-hydroxyl and the shape of the 15-proton signal resembles that of the $15 \beta$-proton signal of $\mathbf{E}$. The other oxygenated functional group was assumed to be involved in a ketone based on the following evidence. Two proton-signals, which must be in geminal by their coupling constants and are assignable to 12-protons, appear in a rather lower field, at $\delta 3.03$ and $3.16 \mathrm{ppm}$. One is observed as a sharp doublet and assigned to the $\alpha$-axial proton. The other appeared as a somewhat broad doublet and was assigned to the $\beta$-equatorial proton which is supposed to have a long range coupling with the $14 \beta$-proton. To confirm the above assignment $\mathbf{E}$ and $\mathbf{F}$ were oxidized with chromic acid and their products were surveyed by GLC and GC-MS. The main products from $\mathbf{E}$ and $\mathbf{F}$ were identical with respect to their retention times and mass spectra, the structure bing assignable to 10. All the evidence described indicates that the structure of $\mathbf{F}$ is $\mathbf{1 1}$.

\section{EXPERIMENTAL}

General. TLC was performed using Silica gel $\mathrm{GF}_{254}$ (Merck) and ethyl acetate-chloroform $(3: 1, \mathrm{v} / \mathrm{v})$. GLC was conducted as described in the preceding paper. ${ }^{1)}$ Melting points were determined with a Yanagimoto micro hot stage apparatus and uncorrected. IR spectra were taken with a JASCO A-202 spectrometer in nujol mull. Mass spectra were taken with a Hitachi RMU-6M spectrometer, using an electron accelerating voltage of $30 \mathrm{eV}$. GC-MS was performed with a Shimadzu-LKB 900B instrument, in which a glass column $(50 \mathrm{~cm} \times 3 \mathrm{~mm})$ packed with $1 \%$ OV-1 on Chromosorb W (100 mesh) was used. Column temperature, $190^{\circ} \mathrm{C}$; carrier gas $(\mathrm{He})$; flow rate, $30 \mathrm{ml} / \mathrm{min}$. NMR spectra were determined in a pyridine- $d_{5}$ solution with a JEOL MH-100 and an FX-400 spectrometer.

Isolation of metabolites from steviol methyl ester (1). G. fujikurol (NRRL strain) was cultured as described in the preceding paper. ${ }^{1)}$ In the third culture, steviol methyl ester $(150 \mathrm{mg})$ was added to the medium $(100 \mathrm{ml} \times 6)$ containing the growth retardant, $N, N, N$-trimethyl-4-cyclohexylbutyl ammonium 1odide $(16,90 \mathrm{mg})$ in conical flasks $(500 \mathrm{ml} \times 6)$ and the culture was continued for 9 days. The culture filtrate was extracted with ethyl acetate and an ethyl acetate-soluble neutral fraction $(427 \mathrm{mg}$ ) was separated by the usual solvent partitioning method. The fraction was then subjected to partition chromatography using a Sephadex LH-20 column $(30 \mathrm{~g}, 2 \mathrm{~cm} \times 30 \mathrm{~cm})$ for a wide range separation. ${ }^{7)}$ Elution was conducted with a mixture of light petroleum-ethyl acetate-acetic acid-methanolwater $(100: 80: 5: 40.7, \mathrm{v} / \mathrm{v} / \mathrm{v} / \mathrm{v} / \mathrm{v}$, upper phase) and the eluate was fractionated for every $15 \mathrm{ml}$ Based on the GLC analysis of each fraction, fractions $11 \sim 21$ were combined and successively purified by TLC. Elution from the zones at $R f 0.37 \sim 0.45,0.45 \sim 0.53$ and $0.53 \sim 0.61$ gave $7 \alpha$ hydroxysteviol methyl ester $(3,8 \mathrm{mg}), 11 \beta$-hydroxysteviol methyl ester $(5,6 \mathrm{mg})$ and $7 \beta$-hydroxysteviol methyl ester $(2,5 \mathrm{mg})$, respectively. Fractions $24 \sim 40$ from the partition column were combined and purified by TLC and from the zone at $R f 0.25 \sim 0.3315 \beta$-hydroxy-11-oxosteviol methyl ester $(11,2 \mathrm{mg})$ was isolated. The combined fractions $41 \sim 68$ contained two metabolites, and from the zones at Rf $0.03 \sim 0.10$ and $0.14 \sim 0.23$ on TLC gave $11 \beta, 15 \alpha$ dihydroxysteviol methyl ester $(9,14 \mathrm{mg})$ and $7 \alpha, 11 \beta$ dihydroxysteviol methyl ester $(6,15 \mathrm{mg})$, respectively. 2,3 and 5 were crystallized from acetone- $n$-hexane. 11 was not crystallized due to its minute quantity. 6 and 9 were crystallized from acetone- $n$-hexane but good crystals were not obtained due to their low solubility.

$7 \alpha$-Hydroxysteviol methyl ester (3). mp $163 \sim 168^{\circ} \mathrm{C}$. IR $v_{\max }^{\mathrm{Nu} \text { ol }} \mathrm{cm}^{-1}: 3500,1714,1660 . \mathrm{MS}^{*} \mathrm{~m} / z$ (relative intensity, $\%): 348\left(\mathrm{M}^{+}, 23\right), 330$ (100), 315 (51), 270 (71), 255 (37). TMS derivative: MS m/z (\%): $492\left(\mathrm{M}^{+}, 100\right), 477$ (9), 433 (5), 402 (66), 281 (80).

$11 \beta$-Hydroxysteviol methyl ester (5). mp $123 \sim 135^{\circ} \mathrm{C}$. IR $v_{\max }^{\mathrm{Nujol}} \mathrm{cm}^{-1}: 3550,3400,1710,1650 . \mathrm{MS} m / z(\%): 348$

* Only significant fragments of over $m / z 200$ are described throughout this paper. 
$\left(\mathrm{M}^{+}, 14\right), 330$ (62), 315 (15), 312 (12), 289 (32), 271 (100), 253 (15). TMS derivative: MS $m / z(\%): 492\left(\mathrm{M}^{+}, 19\right), 477$ (5), 402 (100), 387 (13), 343 (10).

$7 \alpha, 11 \beta$-Dihydroxysteviol methyl ester (6). $\mathrm{mp}$ $218 \sim 222^{\circ} \mathrm{C}$. IR $v_{\max }^{\text {Nujol }} \mathrm{cm}^{-1}: 3540,3370,1680,1620$. MS $m / z(\%): 364\left(\mathrm{M}^{+}, 13\right), 346$ (31), 328 (34), 305 (15), 303 (11), 289 (26), 268 (38), 207 (100). TMS derivative: MS $m / z$ (\%): $580\left(\mathrm{M}^{+}, 57\right), 565$ (12), 490 (93), 475 (18), 400 (33), 309 (37), 295 (40), 281 (100).

$11 \beta, 15 \alpha$-Dihydroxysteviol methyl ester (9). mp $222 \sim 225^{\circ} \mathrm{C}$. IR $v_{\max }^{\mathrm{Nujol}} \mathrm{cm}^{-1}: 3330,1724,1680$. MS $\mathrm{m} / \mathrm{z}$ (\%): $364\left(\mathrm{M}^{+}, 29\right), 346(100), 328$ (84), $316(16), 305$ (13), 303 (13), 289 (55), 269 (76), 268 (92), 253 (42). TMS derivative: $\mathrm{MS} m / z(\%): 580\left(\mathrm{M}^{+}, 72\right), 565(12), 490(100)$, 475 (15), 463 (12), 451 (19), 400 (14), 295 (58), 281 (90).

15ß-Hydroxy-11-oxosteviol methyl ester (11). IR $v_{\max }^{\mathrm{Nujol}}$ $\mathrm{cm}^{-1}: 3270,1718,1695,1645$. MS $m / z(\%): 362\left(\mathrm{M}^{+}, 57\right)$, 344 (100), 330 (40), 303 (50), 284 (93). TMS derivative: MS $m / z(\%): 568\left(\mathrm{M}^{+}, 8\right), 491$ (6), 416 (3), 311 (7), 207 (100).

ent-7 $\beta$-Hydroxykaur-16-en-19-ol (13). Methyl ent-7oxokaur-16-en-19-oate $(4,25 \mathrm{mg})$ was dissolved in THF $(5 \mathrm{ml})$ and treated with $\mathrm{LiAlH}_{4}(20 \mathrm{mg})$ with stirring at room temperature. After $16 \mathrm{hr}, 0.2 \mathrm{ml}$ of water was added to the solution at $0^{\circ} \mathrm{C}$, which was kept for $1 \mathrm{hr}$. The precipitate was filtered off and the filtrate was concentrated into gum, which was purified by TLC to afford $13(17 \mathrm{mg})$. Crystallized from acetone- $n$-hexane. $\mathrm{mp}$ $211 \sim 212^{\circ} \mathrm{C}$. IR $v_{\max }^{\text {Nujol }} \mathrm{cm}^{-1}: 3400,1658$. NMR $\delta(\mathrm{ppm})$ : $1.09,1.22$ (two $\left.3 \mathrm{H}, \mathrm{s}, 18-\mathrm{H}_{3}, 20-\mathrm{H}_{3}\right), 2.07(1 \mathrm{H}$, br. d, $17 \mathrm{~Hz}, 15 \beta-\mathrm{H}), 2.17(1 \mathrm{H}$, br. d, $14 \mathrm{~Hz}, 14 \alpha-\mathrm{H}), 2.19(1 \mathrm{H}$, $\mathrm{dd}, 12 \mathrm{~Hz}, 6 \mathrm{~Hz}, 6 \beta-\mathrm{H}), 2.74(1 \mathrm{H}$, br. s, $13-\mathrm{H}), 3.23(1 \mathrm{H}, \mathrm{dt}$, $17 \mathrm{~Hz}, 3 \mathrm{~Hz}, 15 \alpha-\mathrm{H}), 3.63(1 \mathrm{H}, \mathrm{d}, 11 \mathrm{~Hz}, 19-\mathrm{H}), 3.67(1 \mathrm{H}$, dd, $12 \mathrm{~Hz}, 4 \mathrm{~Hz}, 7-\mathrm{H}), 4.02(1 \mathrm{H}, \mathrm{d}, 11 \mathrm{~Hz}, 19-\mathrm{H}), 4.93,5.00$ (two $1 \mathrm{H}$, br. s, 17- $\mathrm{H}_{2}$ ). MS m/z (\%): $304\left(\mathrm{M}^{+}, 100\right), 289$ (4), 286 (50), 273 (10), 271 (8), 268 (6), 255 (57). TMS derivative: MS $m / z(\%): 448\left(\mathrm{M}^{+}, 15\right), 433$ (3), 358 (73), 343 (6), 268 (85), 255 (100).

Oxidation of $7 \beta$-hydroxysteviol methyl ester (2) and $7 \alpha$ hydroxysteviol methyl ester (3). One hundred micrograms of 2 and 3 were dissolved in acetone $(0.1 \mathrm{ml})$ separately. A drop of Jones reagent was added to the solutions at $0^{\circ} \mathrm{C}$, which were kept for $10 \mathrm{~min}$. The solutions were diluted with acetone $(1 \mathrm{ml})$ and passed through a small column of alumina $(5 \mathrm{~mm} \times 4 \mathrm{~cm})$. After evaporation of the solvent, the residues were analyzed by GLC and GC-MS, directly as well as after trimethylsilylation. The retention times and mass spectra of the main products from 2 and 3 were identical. MS $m / z(\%): 346\left(\mathrm{M}^{+}, 100\right), 331(9), 314(9), 290$ (11), 286 (36). TMS derivative: $\mathrm{MS} m / z(\%): 418\left(\mathrm{M}^{+}, 98\right)$, 403 (10), 359 (5), 209 (100).

$15 \alpha$-Hydroxysteviol methyl ester (7). 1 (100 mg) was dissolved in dioxane $(20 \mathrm{ml})$ and treated with selenium dioxide $(60 \mathrm{mg})$ for $6 \mathrm{hr}$ at room temperature. After evaporation of the solvent, the residue was purified by TLC to afford 7 (48 $\mathrm{mg})$. Crystallized from ethanol. Sublimes at $241 \sim 242^{\circ} \mathrm{C}$. IR $v_{\max }^{\mathrm{Nujol}} \mathrm{cm}^{-1}: 3270,1711,1665$. NMR $\delta$ (ppm): 0.93, 1.17 (two $\left.3 \mathrm{H}, \mathrm{s}, 18-\mathrm{H}_{3}, 20-\mathrm{H}_{3}\right), 3.63(3 \mathrm{H}, \mathrm{s}$, $\left.\mathrm{COOCH}_{3}\right), 4.25\left(1 \mathrm{H}\right.$, br. $\left.\mathrm{s}, \mathrm{W}_{1 / 2}=5.2,15-\mathrm{H}\right), 5.66,5.75$ (two $1 \mathrm{H}$, br. s, 17- $\left.\mathrm{H}_{2}\right)$. MS $m / z(\%): 348\left(\mathrm{M}^{+}, 100\right), 333$ (5), 330 (77), 315 (18), 312 (11), 291 (11), 288 (11), 270 (39), 253 (21). TMS derivative: MS $m / z(\%): 492\left(\mathrm{M}^{+}, 58\right), 477$ (13), 402 (50), 387 (13), 363 (53), 312 (13), 281 (100).

15-Oxosteviol methyl ester $(\mathbf{8}) .7(20 \mathrm{mg})$ was dissolved in pyridine $(1 \mathrm{ml})$ and to the solution was added excess pyridine chromic acid complex. After being kept for $5 \mathrm{hr}$ at room temperature, isopropanol $(0.5 \mathrm{ml})$ was added to the mixture. After $1 \mathrm{hr}$, the mixture was diluted with ethyl acetate and filtered. The solvent was evaporated and the residue was purified by TLC to give $8(12 \mathrm{mg})$. Crystallized from ethyl acetate- $n$-hexane. mp $144 \sim 146^{\circ} \mathrm{C}$. IR $v_{\max }^{\text {Nujol }}$ $\mathrm{cm}^{-1}: 3480,1717,1640$. NMR $\delta$ (ppm): 0.92, 1.20 (two $\left.3 \mathrm{H}, \mathrm{s}, 18-\mathrm{H}_{3}, 20-\mathrm{H}_{3}\right), 3.65\left(3 \mathrm{H}, \mathrm{s}, \mathrm{COOCH}_{3}\right), 5.44,6.04$ (two $1 \mathrm{H}$, br. s, 17- $\left.\mathrm{H}_{2}\right)$. MS $m / z(\%): 346\left(\mathrm{M}^{+}, 100\right), 328$ (18), 318 (40), 287 (39), 286 (28), 268 (25), 253 (19). TMS derivative: MS $m / z(\%): 418\left(\mathrm{M}^{+}, 18\right), 403$ (4), 390 (100), 386 (5), 375 (7), 358 (12), 330 (5), 300 (10).

ent-13,-15 $\alpha$-Dihydroxykaur-16-en-19-ol (14). 8 (7 mg) was treated with $\mathrm{LiAlH}_{4}(8 \mathrm{mg})$ in THF $(2 \mathrm{ml})$ for $16 \mathrm{hr}$ at room temperature. After working up as in the case of $\mathbf{1 3}$, the product was purified by TLC to afford $14(5 \mathrm{mg})$. Crystallized from acetone- $n$-hexane. mp $192 \sim 194^{\circ} \mathrm{C}$. IR $v_{\max }^{\text {Nujol }} \mathrm{cm}^{-1}: 3320,1625$. NMR $\delta$ (ppm): 1.13, 1.19 (two $3 \mathrm{H}, \mathrm{s}, 18-\mathrm{H}_{3}, 20-\mathrm{H}_{3}$ ), 3.67, 4.04 (two $1 \mathrm{H}, \mathrm{d}, 11 \mathrm{~Hz}, 19-\mathrm{H}_{2}$ ), $4.32\left(1 \mathrm{H}\right.$, br. s, with triplet-like shoulders, $\mathrm{W}_{1 / 2}=7 \mathrm{~Hz}, 15-$ H), $5.62(1 \mathrm{H}$, br. t, $1.5 \mathrm{~Hz}, 17-\mathrm{H}), 5.68(1 \mathrm{H}$, br. q, $1.5 \mathrm{~Hz}$, 17-H). MS $m / z(\%): 320\left(\mathrm{M}^{+}, 32\right), 302$ (28), 289 (31), 287 (21), 284 (18), 273 (53), 271 (71), 263 (100), 253 (25), 245 (36), 229 (44), 215 (44). TMS derivative: MS m/z (\%): 536 $\left(\mathrm{M}^{+}, 61\right), 521$ (13), 448 (33), 433 (7), 407 (100), 356 (12), $343(8)$.

Oxidation of 11 $13,15 \alpha$-dihydroxysteviol methyl ester (9) and 15 -hydroxy-11-oxosteviol methyl ester (11). 9 $(0.5 \mathrm{mg})$ and $11(0.1 \mathrm{mg})$ were dissolved in $0.1 \mathrm{ml}$ of acetone-THF mixture $(1: 1, \mathrm{v} / \mathrm{v})$ separately and treated with a drop of Jones reagent. After working up as in the cases of $\mathbf{2}$ and 3, the products were analyzed by GLC and GC-MS. The main products from 9 and 11 were identical, the structure being assumed to be 10. MS $m / z(\%): 360$ $\left(\mathrm{M}^{+}, 56\right) 342$ (20), 332 (16), 328 (12), 314 (12), 301 (100), 300 (72), 283 (44). TMS derivative: $\mathrm{MS} m / z(\%): 432\left(\mathrm{M}^{+}\right.$, 100), 417 (17), 404 (25), 389 (21), 373 (62), 357 (37).

Acid treatment of $7 \alpha, 11 \beta$-dihydroxysteviol methyl ester (6). $6(2 \mathrm{mg})$ was dissolved in $5 \mathrm{ml}$ of acetic acid-water mixture $(1: 9, \mathrm{v} / \mathrm{v})$ and kept at $65^{\circ} \mathrm{C}$ for $8 \mathrm{hr}$. After 
evaporation of the solvent at reduced pressure, the residue was purified by TLC to give a major product $(1 \mathrm{mg})$ with some impurities. IR $v_{\max }^{\mathrm{Nujol}} \mathrm{cm}^{-1}: 3400,1715,1660$. NMR $\delta$ (ppm): 0.96, 1.19 (two $\left.3 \mathrm{H}, \mathrm{s}, 18-\mathrm{H}_{3}, 20-\mathrm{H}_{3}\right), 1.65(3 \mathrm{H}, \mathrm{s}$, $\left.17-\mathrm{H}_{3}\right), 3.60\left(3 \mathrm{H}, \mathrm{s}, \mathrm{COOCH}_{3}\right), 3.77(1 \mathrm{H}$, br. d, $12 \mathrm{~Hz}, 7-$ H), 4.52 (1H, br. s, $\left.\mathrm{W}_{1 / 2}=8 \mathrm{~Hz}, 11-\mathrm{H}\right)$. MS $m / z(\%): 364$ $\left(\mathrm{M}^{+}, 23\right), 348$ (18), 328 (6), 306 (66), 305 (41), 288 (100). TMS derivative: MS m/z (\%): $508\left(\mathrm{M}^{+}, 32\right), 493$ (55), 451 (63), 450 (56), 418 (57), 375 (13), 361 (100).

Acknowledgments. We express our thanks to Mr. K. Furihata, The Institute of Applied Microbiology, The University of Tokyo, for the measurements of $400 \mathrm{MHz}$ NMR spectra and to Dr. K. Aizawa in our Department for his help in the determinations of NMR and mass spectra. We are also grateful to Dr. T. Murai and Dr. C. Tomizawa, National Institute of Agricultural Sciences, for their help in GC-MS analysis.

\section{REFERENCES}

1) N. Murofushi, Y. Shigematsu, S. Nagura and N. Takahashi, Agric. Biol. Chem., 46, 2305 (1982).

2) J. R. Bearder, J. MacMillan and C. M. Wels, Phytochemistry, 14, 1741 (1975).

3) N. Murofushi, Agric. Biol. Chem., 46, 1087 (1982).

4) I. Benes, V. Benesova and V. Herout, Collect. Czech. Chem. Commun., 42, 1229 (1977).

5) W. Herz and R. P. Sharma, J. Org. Chem., 41, 1021 (1976).

6) T. Murakami, H. Iida, N. Tanaka, Y. Saiki, C-M. Chen and Y. Iitaka, Chem. Pharm. Bull., 29, 675 (1981).

7) J. MacMillan and C. M. Wels, J. Chromatogr., 87, 271 (1973). 